MYKOLOROMERIO
UNIVERSITETAS

\title{
CRITICAL POINTS IN DISTANCE LEARNING SYSTEM
}

\author{
Airina Savickaitè \\ Vilnius Gediminas Technical University, Lithuania, airina.savickaite@gmail.com \\ doi:10.13165/ST-13-3-1-15
}

\section{Abstract}

Purpose - This article presents the results of distance learning system analysis, i.e. the critical elements of the distance learning system. The critical points of distance learning are a part of distance education online environment interactivity/community process model. The most important is the fact that the critical point is associated with distance learning participants.

Design/methodology/approach - Comparative review of articles and analysis of distance learning module.

Findings - A modern man is a lifelong learner and distance learning is a way to be a modern person. The focus on a learner and feedback is the most important thing of learning distance system. Also, attention should be paid to the lecture-appropriate knowledge and ability to convey information. Distance system adaptation is the way to improve the learner's learning outcomes.

Research limitations/implications - Different learning disciplines and learning methods may have different critical points.

Practical implications - The information of analysis could be important for both lecturers and students, who studies distance education systems. There are familiar critical points which may deteriorate the quality of learning.

Originality/value - The study sought to develop remote systems for applications in order to improve the quality of knowledge.

Keywords: distance learning, process model, critical points.

Research type: review of literature and general overview.

Socialinès technologijos/Social Technologies

(C) Mykolo Romerio universitetas, 2013

(C) Mykolas Romeris University, 2013
ISSN 2029-7564 (online)

https://www.mruni.eu/lt/mokslo_darbai/st/apie_leidini/

https://www.mruni.eu/en/mokslo_darbai/st/apie_leidini/index.php 


\section{Introduction}

The term "learning" includes all of our personal and social development processes and leads to the statement that life is an endless learning, which demonstrates that living and learning processes are inseparable from each other (Jasinavičus, 2004-2006). All people are able to learn, not only to improve the knowledge and practical skills. At the same time they improve their social environment. A man becomes a role model for his colleagues, but most importantly, to himself. He is always wondering if he can improve more on their well-being. In a modern educational theory and practice particular emphasis is given on the importance of fostering personal excellence. Competence is an ability to perform certain activities on the basis of acquired knowledge, skills, abilities and values in order to be able to gain knowledge of expertise. Also, it is necessary to analyze and explore learning opportunities. Development of science and technology and advances in the production of primary education are becoming a trend which is not referred to as reproducible enhancement of knowledge and effort to understand man and the world (Gudžinskienè, 2007). Learning is a complex and multifaceted process in which an individual is changing gradually in order to become a professional (Rajecko 1999, 2001).

Distance learning is an effective way to encourage people to continue learning. At the same time, it is a broader way of learning in order to gain education and skills (Vaičiūnaite, 2012). Distant education is generally understood as training giving learners an opportunity to study at a convenient time, which is perceived as a satisfactory activity (Kemzūra, 2010).

The aim of this analysis or distance learning processes of risk points are related to the distance learning system of risk points. The results may be useful in improving the system of distance education and personal preparation before starting to learn the remote system. The remote training system could be improved because various survey results show that there is a high dissatisfaction related to the training remotely (Janušienè, 2008) such as:

- Human factor deficiency. Some students wish to have a direct communication with the instructor and other students.

- Lack of feedback. There are fears that studying at a distance, there is no opportunity to consult with the teacher and find out concerns and uncertainties.

- Lack of speaking skills.

- Lack of error correction.

- Lack of objective evaluation.

- Lack of control. Remote courses require self-control and willpower of the learner because he has to study independently.

- Technical and software shortcomings.

\section{Theoretical background}

Human learning, conceived as a witty and motivated activity, self-monitoring, selfrealization and development hypothesis are based on the motivation, so the enhancement 
is perceived as the utmost important. Scientific concept of learning states that learning is a process in which a person sets goals and objectives, learning methods and techniques (Zapolskienè, 2008). According to V. Indrašiene (2001), with the development of science and technology, advances in the production of primary education are becoming not reproducible enhancement of knowledge and effort to understand.

According to V.Gudžinskienè (2008), technology has spreaded education successfully, which can be proven by the following facts:

- In the last decade, the effect of internet usage in education has increased gradually and new technologies have improved students' learning.

- Tremendous improvements in information and communication technologies and increase in the use of the internet has brought lots of opportunities to different fields and, especially, to education.

- Based on new technologies, learning environments are able to provide a wide range of educational alternatives for learners.

Distance learning is an effective way to encourage early drop-outs from schools to continue learning. This is a broader, more flexible approach and it gives more opportunities to learn and acquire education and skills. Moreover, the possibility to provide take-home hardware in distance learning courses has advantages for both students and teachers such as free use of time or practical experience (in contrast to simulators). On the other hand, there are quite a few disadvantages, beginning with problems that there are often no solutions for take-home hardware which then have to be developed by the teachers or the problem that students have to work on their own without any external help (Geyer, 2007).

\section{Research Methodology}

This part of the study presents models of distance learning: distance education online environment interactivity model process and REACT - the basic structure for all human work.

M. Rena (2003) proposed a model which shows the relationship of interactivity and sense of community with students moving from stages of being enrolled in the class to the learner who is actively engaged in the online class (see Figure 1). This model also shows factors that might impact the interactive qualities of the class, which are welldocumented in the literature covering sense of community and interactivity. A variety of factors can affect the interactivity that occurs in the class. These factors can be related to the students, the instructors or the course. Student who enrols in the class brings a variety of traits, which affect participation in the class, e.g., students who do not speak during face-to-face conversations in class may be more comfortable responding to discussion topics because they have more time to formulate their answers.

Course factors may also influence the level of class interactivity. Classes which provide skills, such as accounting of finance, may not be able to provide as much discussion and sense of community as classes that are more theory-based, such as 
management or literature. Just as students and course material are unique, instructors are individuals bringing a distinctive style of teaching developed throughout their teaching careers. Factors such as knowledge about technology, online experience, pedagogical techniques and motivation may also be reflected in the amount and type of interactivity, which is a part of class design (Rena, 2003).

Student enrol in class; online experience; knowledge of technology; writing style

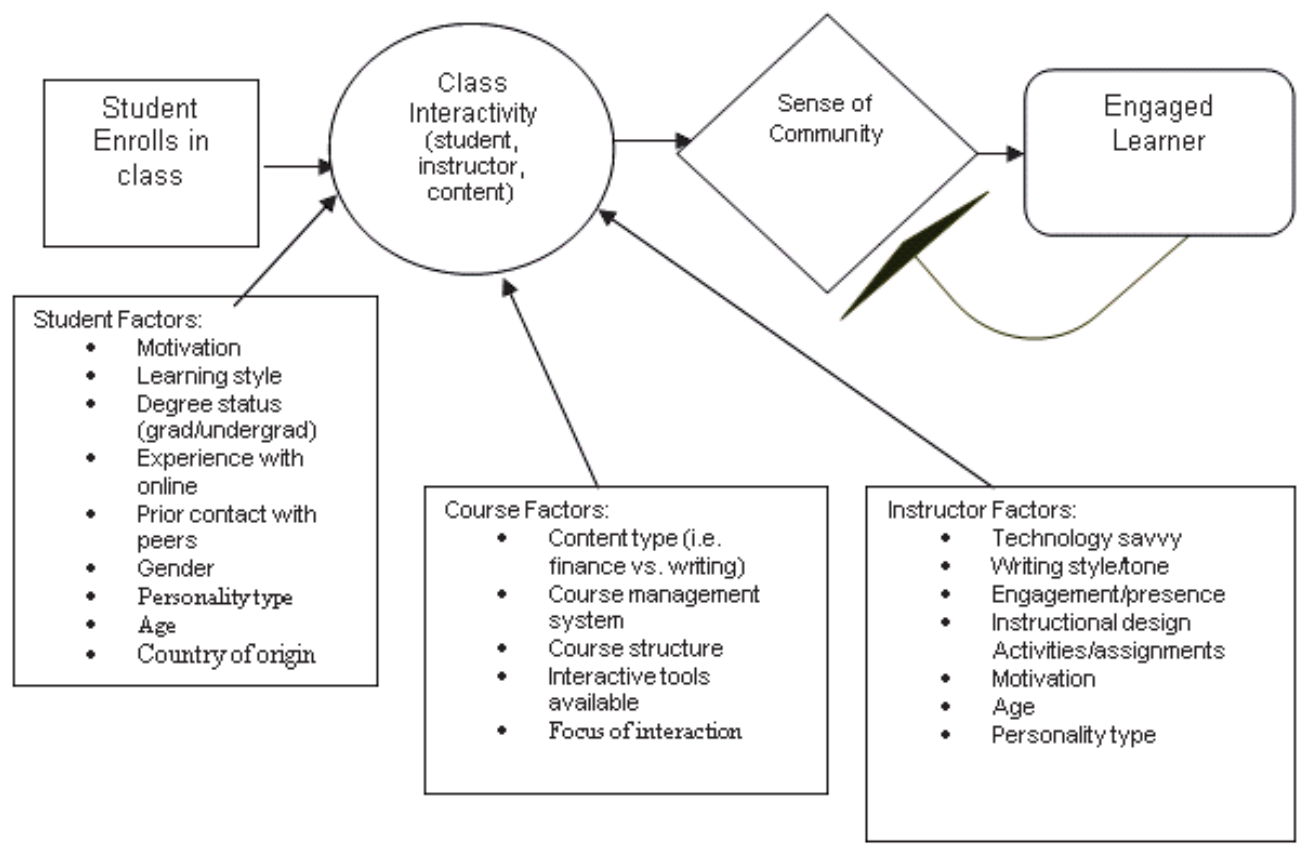

Figure 1. Distance education online environment interactivity/community process model (Lear, 2010).

Figure 2 shows the basic structure for all human work. The basic structure for all human work is important for all learning methods. In order to analyze this model, distance learning is important because the study is seeking to find out how to catch and keep the learner's attention to learning skills. The following analysis presents the most important processes in the case of distance learning. Administrator or lecturer of each distance learning system should consider how to manipulate the learner's attention. The following stages are important in order to achieve better learning outcomes:

- Research - This process helps to access information to understand the purpose for which the information will be used. In distance learning students can define possible target task in texts and possible sources of information. Target flexibility is one of the most important features of starting to learn.

- Evaluate - It refers to the ability to develop and see your own progress. Distance learning participants are more motivated to learn if they can see their level of knowledge and progress. 
- Analyze - It is the ability to make the right decision and to analyze and solve problems.

- Constrain - It defines requirements, procedures and processes which are able to predict the course of analyzing the results.

- Task - It refers to the ability to distribute knowledge and workflows. It also tracks them and reprocesses.

- Access discovery services - These services help to decide where students will go to obtain information and obtain any necessary authorization.

- Identify resources required - From the stages described above students can choose resources of their interests. However, at this stage they have only cursory understanding of their content but what matters is that they are useful.

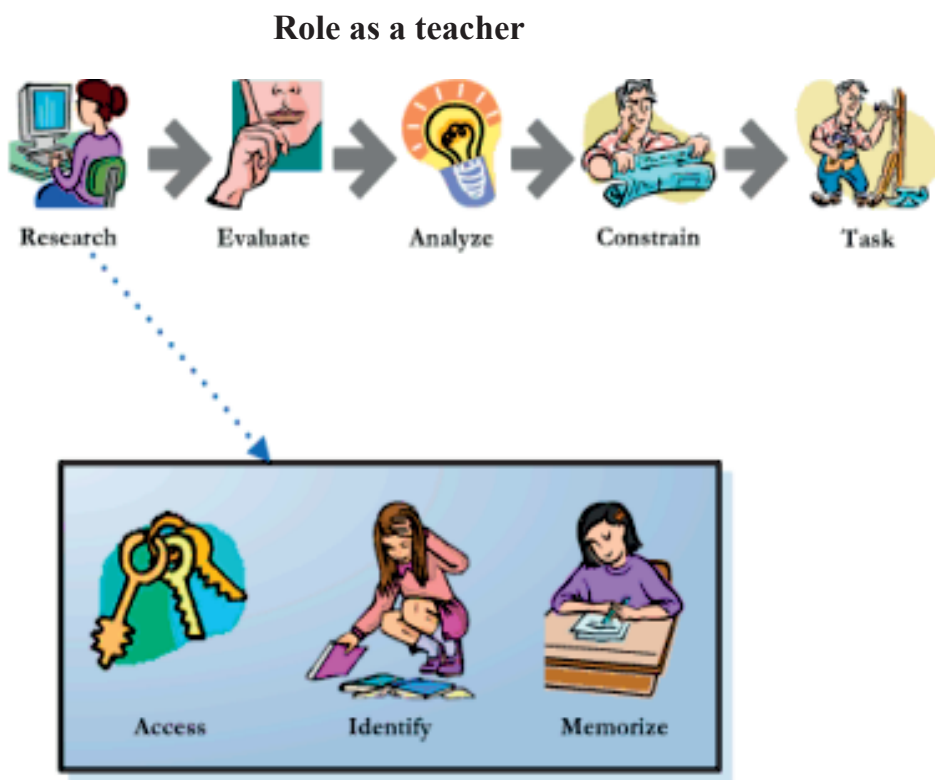

Figure 2. REACT is the basic structure for all human work (Harrison, 2009).

According to the systems approach, teaching with the help of technology involves four major components: course content, the instructor, students and technology tools (see Figure 3). Each component needs to be taken into consideration in order to make technology integration as successful as possible.

Further, each of these components is discussed in more detail:

- Course content - In order to use technology effectively in teaching, course goals have to be examined in the same way as planning a new course. Such question have to be taken into consideration by the instructor: what do you expect students to learn from the course? What skills and knowledge do you want them to acquire by the end of the term?

- The instructor - Once the instructor has a clear view of the course goals and learning objectives and how technology can support students' achievements of 
the goals, the instructor needs to consider some questions about his own skills and confidence: how skilled and experienced are you in using technology? How much time do you have for course planning and selecting teaching strategies suited to your choices of technology? What is your role as an instructor?

- Students - As the instructor adopts technology tools intohis courses, he needs to consider students' previous experience with technology, their expectations and access to technology and the variety of learning styles they bring to the course.

- Technology tools - When the context of teaching and learning has been carefully considered, the technology itself can be examined. One of the challenges everybody confronts is the need to understand the possible uses and functions of an ever-expanding array of technologies. The instructor needs to consider which applications, disciplinary learning, course content, and teaching style are appropriate for the students, It has to be takent into consideration that not all tools are the same. Some are better at promoting learning in specific content areas, while others are useful for a wide range of disciplines. Some technology tools are built for specific instructional goals, while others are more generally applicable.

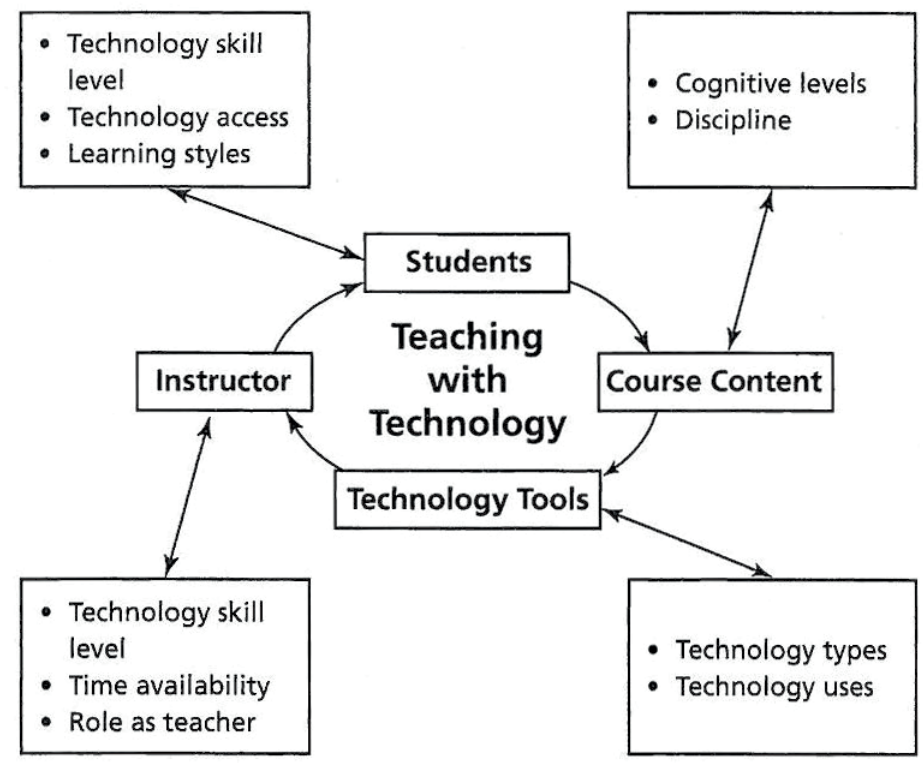

Figure. 3. Teaching with technology ( Zhu, 2014).

Figure 4 is combined with the Figure 1, but factors which are peculiar only to the Figure 4 are highlighted in red. The Figure 4 includes factors which are very important in relation to people's participation in distance education. Motivation and ability to learn at a distance is a good learning performance guarantee. The following detailed list includes factors which are considered important in order to monitor and manage successfully.

- Research - It refers to the ability to analyze information and apply research methods. This factor is required in all forms of studies, especially, in distance 
learning. The ability to study allows not only to get results, but also to consolidate the knowledge and working skills. This ability can be manipulated using a special form of questions or offering specific examples of methods of investigation.

- Evaluate and analyze - It is the ability to evaluate information, knowledge and skills. This ability can be manipulated using a special form of task, offering special investigative techniques such as organizing working groups.

- Constrain and tasks and engagement presence - It refers to the ability to use proper knowledge, information and research method. This is one of the weakest points related to studying remote because it is the ability to recognize when information is used correctly. Even when getting good results, it is likely that knowledge received could be incorrect. This case can be managed by the task problem solving examples.

- Degree status and technology skills level - This status indicates that the learner has the ability not only to learn, but also to study, which means that the learner is able to analyze data. Payment appropriately manages information essential learning remote because the discussion with a lecturer is limited in time and distance.

- Technology access and interactive tools available - It refers to any software and hardware impediment to cease all studies.

Student enrol in class; online experience; knowledge of technology; writing style;

role as a teacher

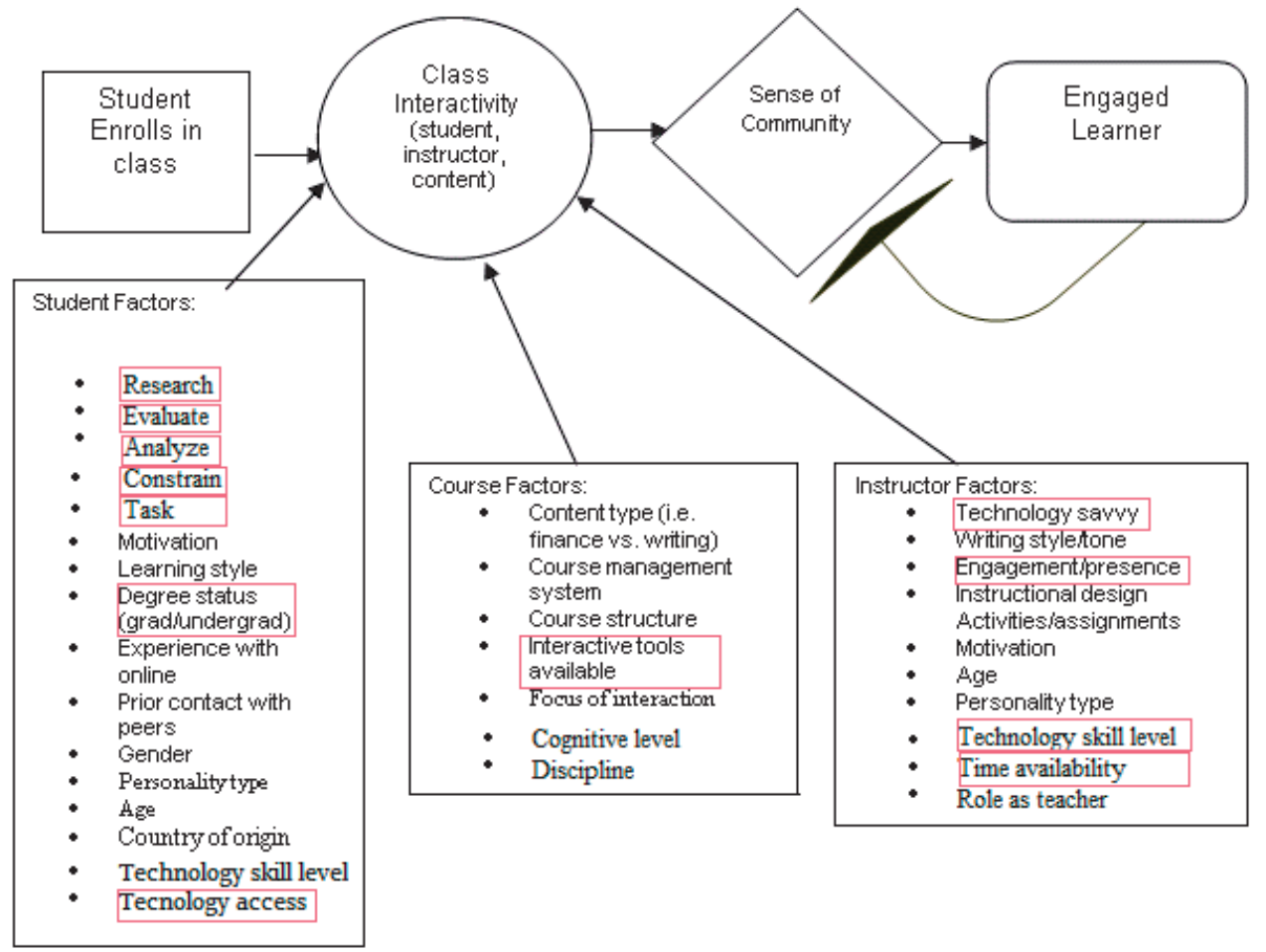

Figure. 4. Critical points of distance learning system 


\section{Conclusions}

1. According to the material of theoretical background, the learning process and distance learning systems are created for a modern person who is seeking for a lifelong learning. Although distance learning has a number of shortcomings, it is still considered to be one way of learning.

Human manipulation is the most important factor of distance learning. Students who learn through distance have the ability to search for information, evaluate, analyse and draw conclusions. The instructor teaches important things such as knowledge as well as considers factors such as participation in teaching and the ability to convey information. There are disadvantages of distance learning, which emphasize the human flaw: lack of vocational education and training supplement, personal advice, feedback or doing some other learner's decisions.

Equivalent human resources cannot be studying people only. Lector's role is also important. Lectors have the ability to properly communicate information, provide their experience and knowledge. Unlike training classroom teacher, the lector should be able to present information in a clear way, have a lot of sources of information, real life examples and solve problems in practice in order not only to provide knowledge, but at the same time to develop students' ability to analyse, adapt information and practical skills.

4. Lastly, the focus on the learner is the most important. There are a lot of ways to keep the learner's attention and one of them is a distance learning system customization/ adaptation, e.g. student knowledge verification analysis of the responses, practical task techniques use analysis, presentation of alternative teaching methods, the results of students development and the results of completed tasks.

\section{References}

Geyer, C. Distance Learning - Advantages and Disadvantages of Take-home Hardware Advantages and Disadvantages of Takehome Hardware. 2007 [interactive]. [accessed on 1-5-2013]. <http://ti.tuwien. ac.at/ecs/teaching/courses/dinf-ws07/papers/ geyer.pdf $>$.

Gružinskiene, V. Teaching and Learning the Concepts of Analysis. 2008 [interactive]. [accessed on 3-1-2013]. <http://www. biblioteka.vpu.lt/pedagogika/PDF/2008/90/ gud49-56.pdf $>$.

Harison, K. Human Interaction Management and Learning. 2009 [interactive]. [accessed on 1-5-2013]. <http://www.bptrends.com/
publicationfiles/11-09-COL\%20Human $\% 20$ Processes-Human\%20Interaction\%20MGTLrng.Harrison-Broninski-20091026fnal. pdf $>$.

Janušienè, J. Remote Teaching (Learning) Applications Continuing Professional Development Training to Stimulate the Development. 2008 [interactive]. [accessed on 1-5-2013]. <http://www.smm.lt/ svietimo_bukle/docs/Nuotolinis_mokymas. pdf $>$.

Jasinavičius, R. Improvement Strategy. 20042006 [interactive]. [accessed on 1-5-2013]. $<$ http://distance.ktu.lt/kursai/verslumas/ verslo_ideologija/fcontent.html $>$. 
Lear, J. L. Interactivity/Community Process Model for the Online Education Environment. 2010 [interactive]. [accessed on 2-25-2013]. $<$ http://jolt.merlot.org/vol6no1/lear_0310. $\mathrm{htm}>$.

Rajecko, V. Learning and Career Development of the Student's Cognitive. 1999 [interactive]. [accessed on 1-25-2013]. <http://www. euroguidance.lt/uploads/files/Mokymosi $\% 20$ ir $\% 20 \mathrm{karjeros} \% 20 \mathrm{galimybiu} \% 20$ pazinimo\%20vadovas\%20studentui[1].pdf $>$.

Rena, M. The Role and Responsibility of the Learner in the Online Classroom 19 $9^{\text {th }} .2003$ [interactive]. [accessed on 2-14-2013]. $<$ http://www.uwex.edu/disted/conference/ Resource_library/proceedings/03_24.pdf $>$.

Zapolskienè, D. How to Increase Adult Motivation to Learn. 2008 [interactive]. [accessed on 1-5-2013]. <http://www. smm.1t/svietimo_bukle/docs/pr_analize/ suaugusiuju_mokymasis.pdf $>$.

Zhu, E. Getting Started with Technology. 2014 [interactive]. [accessed on 2-11-2013]. $<$ http://www.edutopia.org/blog/nationaleducational-technology-standards-students $>$.

\section{KRITINIAI TAŠKAI E-MOKYME}

\section{Airina Savickaite}

Vilniaus Gedimino technikos universitetas, Lietuva, airina.savickaite@gmail.com

Santrauka. Tobulëjančios informacinès ir komunikacinès technologijos išplečia galimybes išsilavinima igyti nuotoliniu büdu. Nuotolinis mokymasis (angl. distance learning) - tai nuoseklus savarankiškas ar grupinis mokymas(is), kai besimokančiuosius ir mokytoją, dèstytoja skiria atstumas ir (ar) laikas, o bendravimas ir bendradarbiavimas, mokymosi medžiaga pateikiama informacinemis ir komunikacinemis technologijomis.

Nuotolinis mokymasis yra veiksmingas büdas skatinti anksti iš švietimo sistemos iškritusius asmenis tęsti mokymasi, mokymasi visa gyvenima ir pan. Tai platesnis, lankstesnis priejimas bei daugiau galimybiu mokytis ir igyti išsilavinima, kvalifikacija. Darbdaviams - tai galimybe lanksčiau, taupant laika ir pinigus organizuoti mokymus ar kvalifikacijos tobulinimo kursus darbo vietoje. Valstybei - tai galimybe didinti švietimo sistemos našuma ir efektyviai naudoti lëšas, suteikti galimybę mokytis tikslinems grupèms (specialiuju ugdymosi poreikiu turintiems asmenims, suaugusiesiems, dirbantiesiems, organizuoti mokytoju rengima, tobulinti mokytojų kvalifikacija ir kt.), skatinti mokymasi visą gyvenimą, didinti švietimo kokybę.

Analizès reikšmè paremta ìvairiu literatūros šaltiniu apžvalga. Nurodoma, kad nuotolinis mokymasis - tai ne tik žiniu gavimas, tai büdas kelti savo kvalifikaciją, keisti socialine aplinka, todèl tikslinga tirti nuotolinio mokymosi etapus, atsižvelgti $i$ trükumus ir svarstyti apie galimus trūkumu taisymus.

Toliau straipsnyje yra nagrinejama nuotolinio mokymosi eiga ir etapai. Analizuojami nuotolinio mokymosi sistemos veikimo etapai ir besimokančiojo žmogaus mokymosi etapai. Analizès tikslas - išskirti visu anksčiau pateiktu etapu kritinius taškus. Kritiniais taškais vadinamos tos dalys, kuriu veikimui sutrikus rezultatas bütu nepasiekiamas. Tai yra asmenys, besimokantys nuotoliniu büdu, neisisavintu visai (arba pakankamai gerai) mokymosi medžiagos. 
Reikšminga yra tai, kad daugiausiai kritiniu tašku turi žmogiškosios savybès. Visi žmogiskieji mokymosi etapai yra kritiniai: informacijos paieška, informacijos suvokimas, informacijos analize ir panaudojimas. Kitas kritinis taškas yra lektoriaus žinios ir darbo igūudžiai. Svarbus klausimas yra "Ar tinkamos lektoriaus žinios ir praktine patirtis pagal mokymosi programa?" Taip pat svarbu lektoriaus gebejjimai perteikti informacija. Nuotolinio mokymo sistemos naudojimo etapo kritinis taškas yra vienas - sistemos tikimybè, kad sistema sklandžiai nedirbs.

Straipsnio išvadose pateikiami galimi sprendimo büdai, kryptys, kurios, jei neišsprendžia problemos, tai bent priartina prie geresniu mokymosi nuotoliniu büdu rezultatu. Isvadose pateikiama informacija svarbi besimokančiajam ir lektoriui, taip pat minimas galimas sistemos adaptavimas: besimokančiuju žiniu patikros atsakymu analizè, praktiniu užduočiu atlikimo metodu taikymo analize, alternatyviu mokymo metodu pavyzdžiu pateikimas pagal gautus rezultatus, besimokančiojo tobulèjimo rezultatai pagal atliktu užduočiu rezultatus.

Raktažodžiai: nuotolinis mokymasis, proceso modelis, kritiniai taškai. 